UC-NRLF

|||||||||.|.||||||||||||||||||||||||||||||||||||||

흐 295 190 


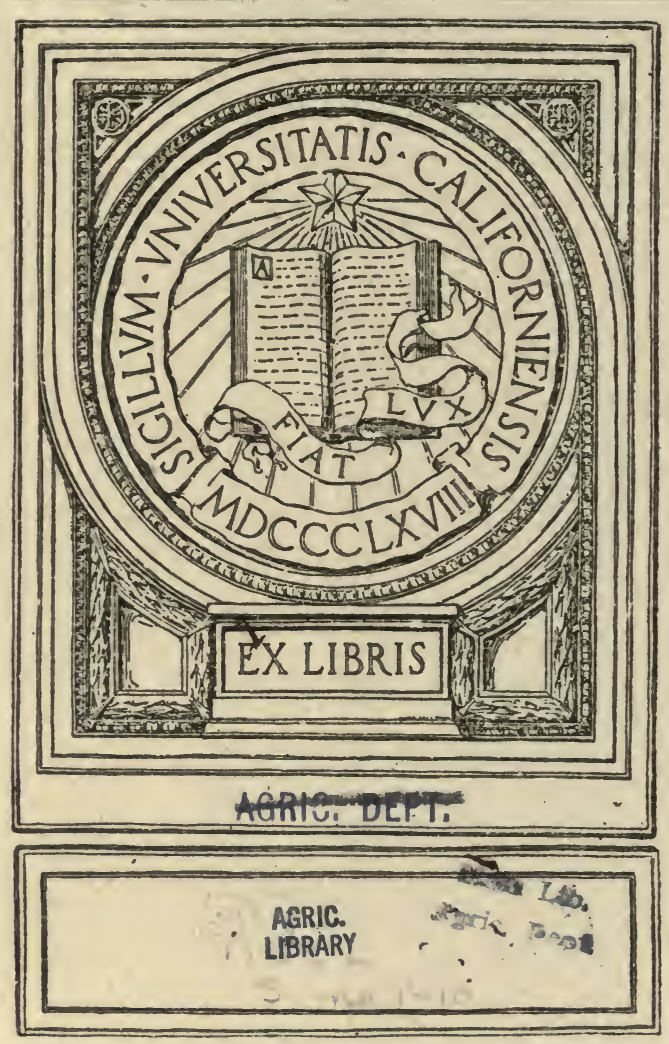




\section{DEPARTMENT OF ACRICULTURE;}

NEW SOUTII WALES.

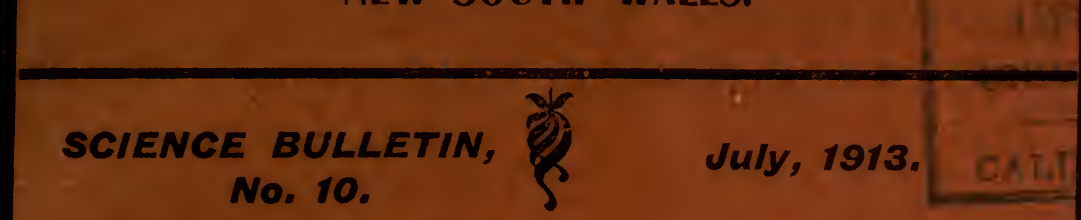

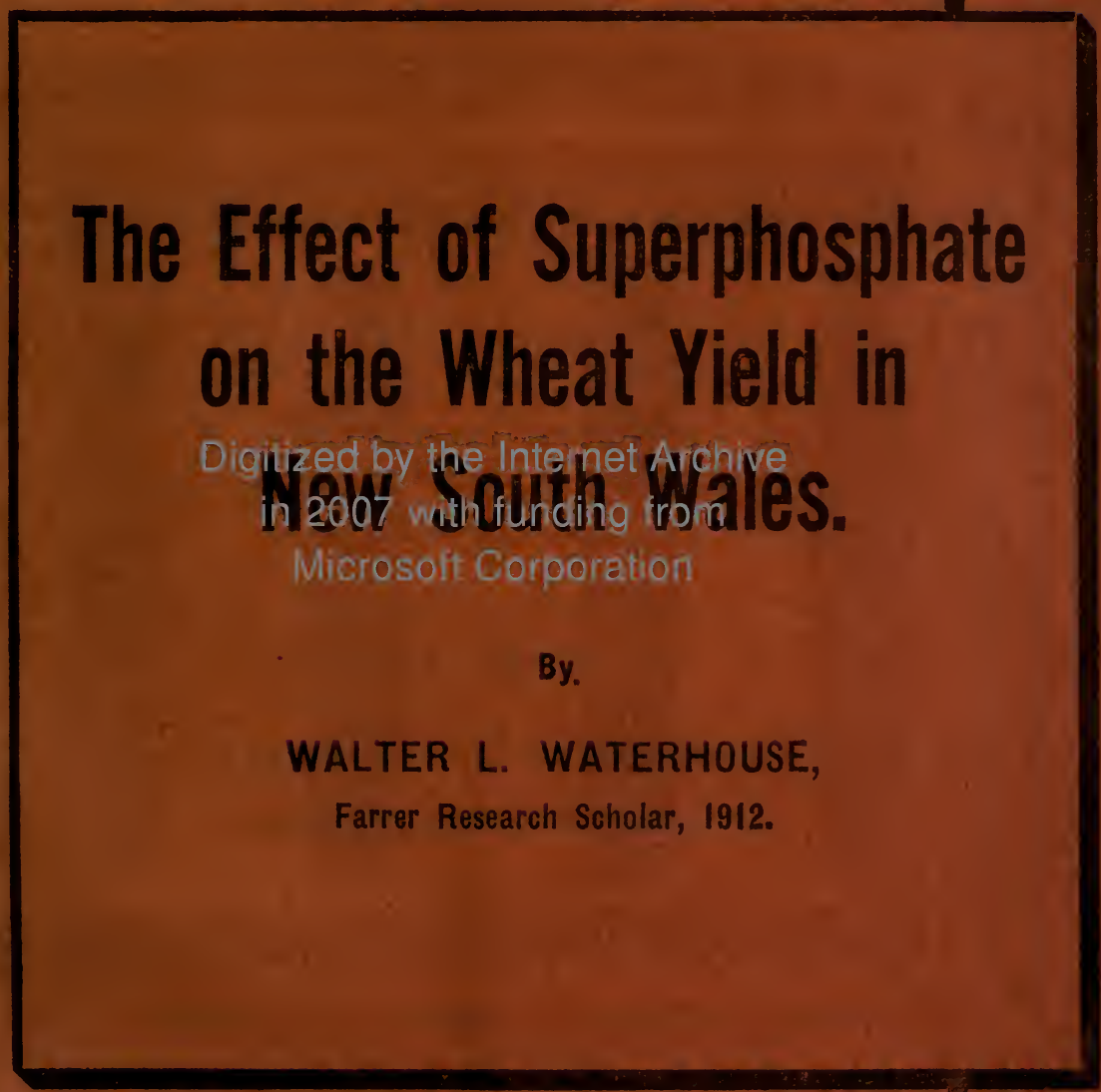

Workers in the respective branches of Economic Science covered by this series of Science Bulletins will receive such of them as may be of use in their special branches of study upon application to the Under Secretary, Department of Agriculture, Sydney. http://www.archive.org/details/effectofsuperpho00waterich 
$a$

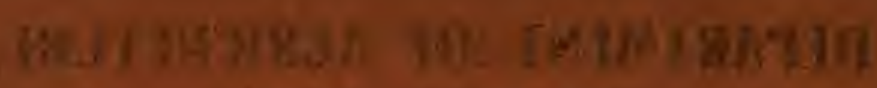
the 4 , 45 ing 41

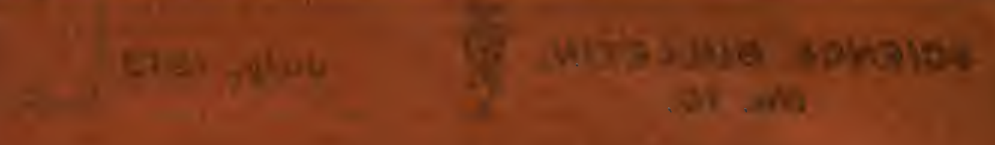

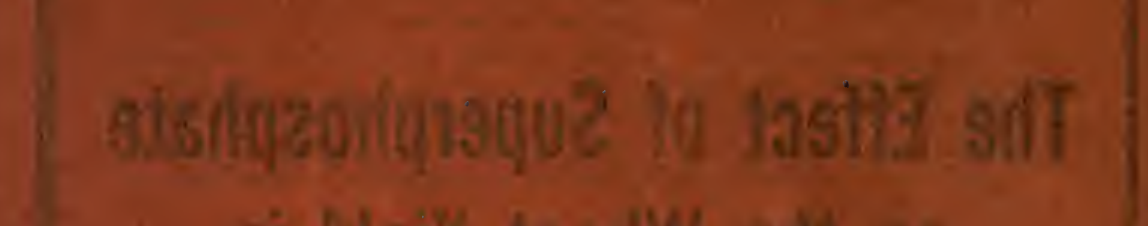

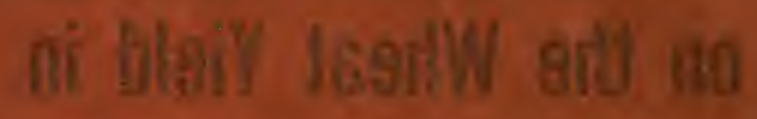
2olsu titnoz walk

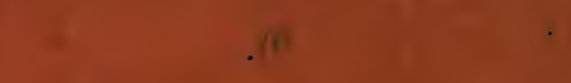

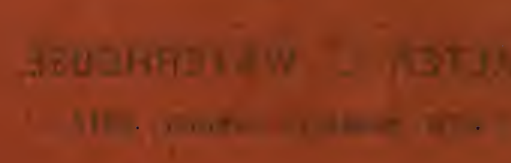

(n) 


\section{DEPARTMENT OF AGRICULTURE,} NEW SOUTII WALES.

\section{SCIENCE BULLETIN, No. 10.}

\section{The Effect of Superphosphate on the Wheat Yield in New South Wales.}

BY

IVALTER L. WATERHOUSE,

Farrer Research Scholar, Igr 2.

SYDNEY: IVILLIAM APPLEGATE GULLICK, GOVERNMENT PRINTER. 


\section{PREFATORY NOTE.}

THE following paper by Mr. W. L. Waterhouse, the first Farrer research scholar, deserves a few words of introduction, explanatory of the genesis and objects of the fund under whose auspices it is published. The Farrer Memorial Fund was subscribed as a result of an appeal to the public, and particularly to those in any way interested in the wheat industry, to perpetuate the memory of the late William J. Farrer, whose success in the production of new varieties of wheat has increased enormously, not only the possibiiities of production, but also the commercial value of Australian grain. The committee of the memorial fund, after considering several suggestions, agreed that the memory of this indefatigable worker could best be honoured by encouraging likely investigators to continue the work with which Farrer's name will always be associatedthe improvement of wheat. It was therefore decided that the interest on the money subscribed should provide for the endowment of a scholarship, to be known as the "Farrer Research Scholarship," to be awarded to the applicant most likely to contribute towards the object aimed at, either by original work in the field, or in the laboratory, or in the mill or rbakehouse, or by a combination of any of these.

With this object a board of five trustees was appointed in October, 1911, to include as ex-efficio members the Under-Secretary for Agriculture and the Principal of the Hawkesbury College, in order to administer the fund. The amount then at the disposal of the trustees was $£ 1,030$. To this sum the Government has generously added $£ 50$ annually.

Applications were invited early in 1912, and as a result, Mr. IV. L. Waterhouse, a student passing through his course in agriculture at the University, was awarded the schoiarship for that year. It was understood that Mr. Waterhouse would not be able to devote the whole of his time to the investigation; but as Professor Watt (Professor of Agrieulture at the University) had kindly promised to direct and supervise his work, it was thought that a satisfactory commencement could be made and the subscribers to the fund assured that their desires were being realised as well as was possible under the circumstances.

Mr. Waterhouse's paper is, it will be admitted, of considerable value in elucidating the question of the nature of soils suitable for wheat culture and their proper manuring. It is a practical, well-worked-out thesis, and a distinct contribution towards the subject of improvement in wheat production.

IVith regard to present and future operations, the trustees take this opportunity of explaining the present position of affairs.

Applications were again invited early in the present year (1913), and again the only suitable candidates were unable to devote more than a portion of their time to investigation.

As the trustees only disposed of a part of the sum available in 1912, and they are now in a position to offer a larger sum, it was felt that it would be better to withhold the scholarship for the present, and to invite applications again next year, when they will be able to offer a sufficiently substantial amount to recompense the recipient for devoting all his time to the work.

They are even h speful that it may be possible to offer a student the opportunity of pursuing his studies at some institution abroad for a year or two, where he could study the most recent scientific developments in this special line of research.

In conclusion, the trustees venture to remind readers of this thesis that the fund is still open to receive contributions, and that the sum so far subscribed represents in a very inadequate manner the value of Farrer's work. Those, therefore, who have benefited by the results of his unselfish lahours, or who desire to perpetuate his memory in such a way as to benefit the conmunity, can still do so by forwarding a subscription, however small, to the secretary of the Farrer Memorial Fund, Department of Agriculture, Sydney.

H. C. L. ANDERSON,

H. W. POTTS,

G. IV. WALKER,

F. B. GUTHRIE,

HENRY LORD,
Trustees of the Farrer Memorial Fund, 


\section{Department OF AgRiculture,}

NEW SOUTH WALES.

\section{SCIENCE BULLETIN, No. 10.}

\section{The Effect of Superphosphate on the Wheat Yield in New South Wales.}

WALTER L. WATERHOUSE,

Farrer Research Scholar, 1912.

For some time it has been known that the manuring of wheat land with superphosphate has met with varying results in different parts of New South Wales. While in very many cases largely increased yields have been obtained as a direct result, there are also instances in which no beneficial effect has accrued, and others in which the fertiliser has apparently been responsible for a diminished return.

The manurial experiments carried out by the New South Wales Department of Agriculture have already done much to throw light on the problem. In the Agricultural Guzette of New South Wales, Vol. XXIII, Part 5, is published an article on "Superphosphate for Wheat," in which it is pointed out that an important principle for the guidance of farmers in manuring wheat land is indicated by the results of manurial experiments carried out in the years 1909, 1910, and 1911. "If these results are maintained in succeeding years, it will be clear that the beneficial effect of superphosphate decreases as we go north. On the south-western slopes and in Riverina, the benefit derived from the application of about $\frac{1}{\mathrm{cwt}}$. of superphosphate per acre is most marked. In the western districts, the central portion of the wheat belt, there is still a considerable advantage, but it is by no means as great as in the south. In the north-western districts, the northern portion of the belt, the average yields indicate that the benefit to be derived from superphosphate is not sufficient to cover the cost of purchasing and applying the manure."

These tentative conclusions are fully justified by the table of average yields published and here reproduced in slightly modified form.

TABLE I.-Showing Average Yields in Manurial Trials, 1909-11, in Farmers' Whea Experiment Plots.

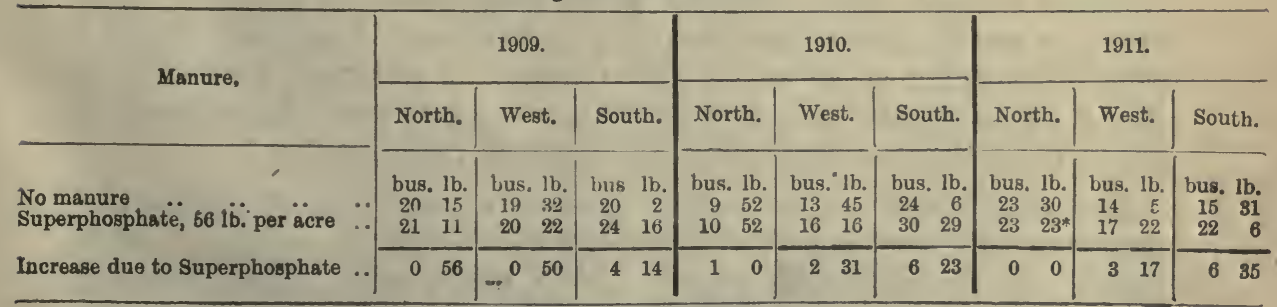

* $42 \mathrm{lb}$. Superphosphate peracre. 
Thus the highly interesting problem of accounting for the diversity in the action of the phosphatic fertiliser is presented.

The investigation of which the results are here submitted, deals with one important factor entering into the problem, viz., the soil constitution. The scheme of work was devised by Professor Watt, of the University of Sydney, and the work carried out in the University laboratory.

With regard to previous literature dealing with the effect of superphosphate on the wheat yield, there is but little available dealing with New South Wales conditions. Experiments have been conducted by the Department of Agriculture, and the results published from time to time in The Agricultural Gazette of New South Wales; these publications are well summarised in the article quoted at the commencement of this paper.

IIall ("Fertilisers and Manures," pages 139 and 140) calls attention to the stimulating effect of the fertiliser on root development. "The action of phosphoric acid on the plant is not confined to its ripening effect; it stimulates the early development of the young seedling to a remarkable extent. . . . . It may also go to explain the extraordinary results of quite small dressings of phosphoric acid upon soils in Southern Australia, where a manuring with half a ewt. per acre or even less of superphosphate has been found sometimes to double the yield of cereals. On analysis the soils are not rich, but they show no such signal deficiency in phosphoric acid as would account for the action of the manure; it seems much more likely that in a semi-arid country where the whole success of the crop depends on the roots getting quickly down to the cooler and moister stib-. soil, the stimulating action of the phosphoric acid upon the young roots becomes of the greatest value."

In a paper read before the Australian $\Lambda$ ssociation for the $\Lambda$ dvancenent of Science this year, Professor Watt presented facts which bear out this contention as regards New South Wales conditions.

Little, however, seems to have been done in the direction of accounting for the variation in the effect of the fertiliser in different parts of the wheat belt. Mr. A. H. E. MeDonald, Inspector of Agriculture for the North-Western Division, states: "Possibly the greater temperatures of the north and the summer rains may be partly responsible for the failure of the soil to respond to fertilisers. Probably these conditions wonld be more favourabie to the liberation of inert plant-food material. The scason is almost a month earlier than that of the south; that is, the erops are ripe nearly a month earlier than they are in Riverina. Last year (1011) I started harresting at Moree on 11th October. I feel sure, however, that nearly all the wheat land in the north-west is very rich; the presence of varied vegetation and especially many legumes, indicates that."

In a consideration of the problem it would appear to be of fundamental importance to know something of the amount and the state of "availability" of the phosphates present in the wheat soils: While realising that a chemical analysis is of itself insufficient as a means of judging the 
cropping capacity of a soil, it was hoped that a comparison of the aulyses - as regards the phosphoric acid content-of a number of specially chosen wheat suils might reveal some interesting information.

In his ciassical work, as a result of which the citric acid method of determining the availability of the phosphoric acid and potash in soils was put forward, Dr. Dyer utilised Rothamsted soils of known cropping powcrs. IIe arrived at certain figires which were of value in determining whether Engiish soils wore likely to be benefited or otherwise by the application of fertilisers. In our New South Wales wheat belt we have one crop, wheat, to consider; and as the climatic conditions are to a large extent the same for this belt, it was hoped that a figure might be obtained representing the amount of available phosphoric acid contained in the soil, which would serve to indicate whether the application of a phosphatic fertiliser is to be recommended or not.

For the purpose of the investigation, samples of soil were obtained from selected farms in different parts of the wheat belt on which manurial experiments with superphosphate have been carried out. The actual returns obtained from these soils in the manured and unmanured state are available, and as the experiments have been conducted under the supervision of the Inspectors of Agriculture, the figures quoted are reliable.

The following is a list of the localities and farms from which the soils were obtained:-二

Table II._- Showing Source of Soil Samples.

\begin{tabular}{|c|c|c|c|c|c|c|c|}
\hline Soil No. & & rrm. & & & Locality. & & Sender. \\
\hline $\begin{array}{r}2 \\
3 \\
10 \\
11 \\
22\end{array}$ & $\begin{array}{l}\text { Government } \\
\text { A. Eulenstein } \\
\text { T. H. Davis } \\
\text { G. Laidlaw } \\
\text { N. Forsyth }\end{array}$ & $\begin{array}{l}\text { xpe } \\
\cdots \\
\cdots \\
\cdots \\
\cdots\end{array}$ & $\begin{array}{l}\text { hent } \\
\cdots \\
\cdots \\
\cdots \\
\cdots\end{array}$ & $\begin{array}{l}\mathrm{arm} \\
\ldots \\
\ldots \\
\ldots \\
\ldots\end{array}$ & $\begin{array}{l}\text { Wagga } \quad . . \\
\text { Henty } \quad \ldots \\
\text { Lockhart ... } \\
\text { Albury ... } \\
\text { Narrandera }\end{array}$ & \begin{tabular}{l|l}
$\cdots$ \\
$\cdots$ \\
$\cdots$ \\
$\cdots$ \\
$\cdots$
\end{tabular} & $\begin{array}{l}\text { (x. M. MeKeown. } \\
\text { H. C. Stening. } \\
\text { do } \\
\text { do } \\
\text { Professor Watt. }\end{array}$ \\
\hline $\begin{array}{l}20 \\
18^{*} \\
21 \\
19^{*}\end{array}$ & $\begin{array}{l}\text { - Black } \\
\text { do } \\
\text { T. Bragg } \\
\text { do }\end{array}$ & $\begin{array}{l}\cdots \\
\cdots \\
\cdots \\
\cdots\end{array}$ & $\begin{array}{l}\cdots \\
\cdots \\
\cdots \\
\cdots\end{array}$ & $\begin{array}{l}\cdots \\
\cdots \\
\cdots \\
\cdots\end{array}$ & $\begin{array}{c}\text { Cumnock ... } \\
\text { dlo } \ldots . \\
\text { Mungeribar } \\
\text { do } \quad . .\end{array}$ & \begin{tabular}{l|}
$\cdots$ \\
$\cdots$ \\
$\cdots$ \\
$\cdots$
\end{tabular} & $\begin{array}{l}\text { H. C. Wilson. } \\
\text { do } \\
\text { do } \\
\text { do }\end{array}$ \\
\hline 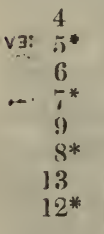 & $\begin{array}{l}\text { S. Forge } \\
\text { do } \\
\text { Dr. Hughes } \\
\text { do } \\
\text { J. Marshall } \\
\text { do } \\
\text { W. Tonkin } \\
\text { do }\end{array}$ & $\begin{array}{l}\cdots \\
\cdots \\
\cdots \\
\cdots \\
\cdots \\
\cdots \\
\cdots\end{array}$ & $\begin{array}{l}\cdots \\
\cdots \\
\cdots \\
\cdots \\
\cdots \\
\cdots \\
\cdots\end{array}$ & $\begin{array}{l}\cdots \\
\cdots \\
\cdots \\
\cdots \\
\cdots \\
\cdots \\
\cdots \\
. .\end{array}$ & 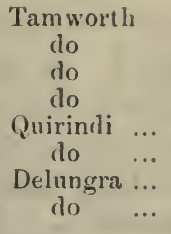 & \begin{tabular}{l|l}
$\cdots$ \\
$\cdots$ \\
$\cdots$ \\
$\cdots$ \\
$\cdots$ \\
$\cdots$ \\
$\cdots$ \\
$\cdots$
\end{tabular} & $\begin{array}{l}\text { A. H. W. McDonald. } \\
\text { do } \\
\text { do } \\
\text { do } \\
\text { do } \\
\text { do } \\
\text { dlo } \\
\text { do }\end{array}$ \\
\hline
\end{tabular}

'The effect of superphosplate on these soils is shown in the following table; the figures are taken from The Agricultural Gazelte of New South Wales, 1909 results in Vol. XXI, page $676 ; 1910$ results in Vol. XXII. Fart 4; and 1911 recsults in Vol, XXIII, Part 4. 
Table III.-Showing Results of Manurial Experiments with Superphosphate.

\begin{tabular}{|c|c|c|c|c|c|c|c|c|c|}
\hline \multirow{2}{*}{\multicolumn{2}{|c|}{ Soil No. }} & \multirow{2}{*}{ Localitý. } & \multicolumn{3}{|c|}{1909.} & \multicolumn{2}{|c|}{1910.} & \multicolumn{2}{|c|}{1911.} \\
\hline & & & & Unmanured. & Manured. & Unmanured. & Manured. & Unmanured. & Manured. \\
\hline 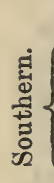 & $\left\{\begin{array}{r}2 \\
3 \\
10 \\
11 \\
22\end{array}\right.$ & $\begin{array}{l}\text { Wagga } \\
\text { Henty } \\
\text { Lockhart } \\
\text { Albury } \\
\text { Narrandera }\end{array}$ & & 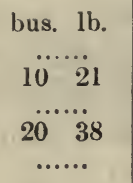 & $\begin{array}{c}\text { bus. lb. } \\
\ldots \ldots . . \\
18^{54} \\
\ldots \ldots . . \\
23^{4} 4 \\
\ldots \ldots .\end{array}$ & $\begin{array}{c}\text { bus. } 1 \mathrm{~b} . \\
14 \quad 58 \\
\ldots \ldots . \\
\ldots \ldots . \\
\ldots \ldots \\
\ldots . .\end{array}$ & $\begin{array}{c}\text { bus. } 1 \text { b. } \\
25 \quad 28 \\
\ldots \ldots \\
\ldots \ldots \\
\ldots \ldots \\
\ldots \ldots\end{array}$ & $\begin{array}{rr}\text { bus. } & \text { lb. } \\
10 & 33 \\
11 & 45 \\
4 & 28 \\
19 & 38 \\
\ldots \ldots\end{array}$ & $\begin{array}{cc}\text { bus. } & \text { lb. } \\
16 & 36 \\
21 & 13 \\
15 & 15 \\
26 & 8 \\
\ldots \ldots\end{array}$ \\
\hline 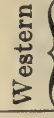 & $\left\{\begin{array}{l}20 \\
21\end{array}\right.$ & $\begin{array}{l}\text { Cumnock } \\
\text { Mungeribar }\end{array}$ & & $\begin{array}{ll}19 & 28 \\
18 & 47\end{array}$ & $\begin{array}{ll}23 & 30^{*} \\
11 & 42^{*}\end{array}$ & $\begin{array}{c}18 \quad 50 \\
\ldots \ldots\end{array}$ & $\begin{array}{c}2320^{*} \\
\ldots \ldots\end{array}$ & $\begin{array}{rr}6 & 55 \\
15 & 49\end{array}$ & $\begin{array}{ll}16 & 44 \\
20 & 42\end{array}$ \\
\hline 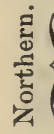 & $\left\{\begin{array}{r}4 \\
6 \\
9 \\
13\end{array}\right.$ & $\begin{array}{l}\text { Tamworth } \\
\text { do } \\
\text { Quirindi } \\
\text { Delungra }\end{array}$ & . & $\begin{array}{rr}16 & 47 \\
\ldots \ldots & \\
22 & 36 \\
26 & 8\end{array}$ & $\begin{array}{ll}17 & 47^{*} \\
\ldots \ldots \ldots \\
22 & 15^{*} \\
25 & 35\end{array}$ & $\begin{array}{lc}6 & 30 \\
\ldots \ldots & \ldots \\
\ldots \ldots & . \\
9 & 50\end{array}$ & $\begin{array}{c}\$ \quad 42 \\
\ldots \ldots \\
\ldots \ldots \\
10 \quad 44\end{array}$ & 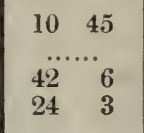 & $\begin{array}{cc}10 & 13 \\
\ldots \ldots \ldots \\
42 & 46 \\
24 & 36\end{array}$ \\
\hline
\end{tabular}

Results marked with an asterisk $(*)$ were obtained frum farms other than those from which the actual soil samples used were taken.

From this table it is seen that the soils from the localities chosen give results which in general correspond to the average results obtained in the three divisions, and quoted at the commencement of this paper: those from the Southern Division are responsive; the Western soils show a decrease in responsiveness as we proceed from south to north; while in the North-West the soils are unresponsive to the phosphatic fertiliser.

Two or three of the soils call for special comment. With regard to Soil No. 22 from Narrandera, Professor Watt states that the paddock in question had been cropped with wheat for a number of years and practically abandoned as exhausted. No superphosphate had ever been used on the farm. Last year the crop was an entire failure on the unmanured portion, while the manured section gave a return of 12 bushels per acre. This great difference was largely explained by the contrast in root development in the two cases.

Soil No. 21 from Mungerikar has given conflicting results. In 1909 the application of superphosphatc was responsible for a decreased return, while in 1911 the manured plots showed an increase of 5 bushels. The soil is termed by Mr. H. C. Wilson, late Inspector of Agriculture for the Western Division, an unresponsive one.

Referring to Soil No. 6 from Tamworth, Mr. A. H. E. McDonald, says: "I am told that this soil has been cropped for fourteen years. Superphosphate (56 lb. per acre) was used last year on immediately adjacent soil with very gcod results. More grain was obtained and the sample was much better." 
At the outset of the investigation, before commencing work with the soils, several of the recommended methods for the estimation of phosphoric acid were tested. Of the official methods, "The Provisional Official Method" (Wiley, "Principles and Practice of Agricultural Analysis," Vol. I, page 514) was chosen as likely to give consistently accurate results with a minimum expenditure of time and labour. The following is an outline of the method:-

To the solution containing the phosphate, 20 c.c. of nitric acid and 25 c.c. of 50 per cent. ammonium nitrate solution were added, and the liquid heated to 50 degrees C. A solution of ammonium molybdate was also brought to this temperature, and sufficient to ensure the complete precipitation of the phosphate as ammonium phospho-molybdate added slowly and with constant stirring, the vessel then being stood in a warm place until precipitation was completed. The yellow precipitate of ammonium phosphomolybdate was filtered off and washed free from acid with a 1 per cent. solution of sodium nitrate. With the filter paper the precipitate was transferred to the beaker used for precipitation, and the precipitate dissolved in excess of standard sodium hydrate soluticn containing 323.7 c.c. of normal sodium hydrate per litre; hence 1 c.c. of the solution was equivalent to 001 or of $\mathrm{P}_{2} \mathrm{O}_{3}$. Special precautions were taken to prevent the carbonation of this solution through contact with carbon dioxide, by the use-of soda-lime tubes. Phenolphthalein was added as indicator, and the excess of alkali over that used in dissolving the yellow precipitate neutralised with a standard solution of hydrochloric acid equivalent to the sodium hydrate solution. The amount of sodium hydrate used in dissolving the precipitate was thus determined, and from this the equivalent amount of $\mathrm{P}_{2} \mathrm{O}_{s}$ calculated.

Haring decided upon the method to be adopted, and having proved it by determining the $\mathrm{P}_{2} \mathrm{O}_{5}$ present in solutions containing known quantities of pure salts, the work of determining the amount. of $\mathrm{P}_{2} \mathrm{O}_{5}$ in the soils submitted was commenced.

For the estimation of the total $\mathrm{P}_{2} \mathrm{O}_{5}, 10 \mathrm{gr}$. of the fine soil was used. This was boiled for ten hours in a conical flask fitted with air-condenser, with 100 c.c. of hydrochloric acid of constant boiling strength. The flask was thoroughly shaken each hour, and at the end of the ten hours the extract filtered and the residue washed till free from chlorides. This extract was then evaporated to dryness with nitric acid, and after heating for some time, moistened with hydrochloric acid, taken up with hot water and filtered. This operation was repeated and then the $\mathrm{P}_{2} \mathrm{O}_{5}$ precipitated and estimated by the method described.

Two hundred grams of the air-dried soil was taken for the determination of the available $\mathrm{P}_{2} \mathrm{O}_{5}$. This was placed in a Winchester flask with 20 grams of citric acid and 2,000 c.c. of distilled water, and the whole agitated for twenty-four hours. After allowing the soil to settle, the supernatant liquid 
was filtered. Of this filtrate 500 c.e. was evaporated to dryness with nitric acid, ignited, moistened with hydrochloric acid, and heated for some time. The residue was then moistened with hydrochloric acid, taken up with hot water and filtered. This operation was repeated to ensure the removal of all silica, and the $\mathrm{P}_{2} \mathrm{O}_{3}$ precipitated and estimated as before.

In each case the amount of moisture present in the soil was determined, and the results calculated as percentage of $\mathrm{P}_{2} \mathrm{O}_{3}$ present in the dry soil.

A trial estimation of the amount of $\mathrm{P}_{2} \mathrm{O}_{5}$ soluble in carbon dioxide solution was made, following the method described by Wiley in his "Principles and Practice of Agricultural Analysis," Vol. I, page 386. Owing to mechanical diffieulties involved, the method was discarded as imprneticable. It may be mentioned that in the soil used (a Wagga sample) the amount of $\mathrm{P}_{2} \mathrm{O}_{5}$ thus determined was only $\cdot 00008$ per eent.

The following is a table of the results obtained, the $\mathrm{P}_{2} \mathrm{O}_{5}$ being calculated as amounts present per 100 of dry soil :-

TABLE IV.-Showing Total and Available Phosphoric Acid.

\begin{tabular}{|c|c|c|c|c|c|}
\hline Soil Number. & Locality. & & Total $\mathrm{P}_{2} \mathrm{O}_{5}$. & Mr. Guthrie's Ratings. & Arailable $\mathrm{P}_{2} \mathrm{O}_{3}$ \\
\hline $\begin{array}{r}2 \\
3 \\
10 \\
11 \\
22\end{array}$ & $\begin{array}{ll}\text { Wagga } & \ldots \\
\text { Henty } & \ldots \\
\text { Lockhart } & . . \\
\text { Albury } & . . \\
\text { Narrandera }\end{array}$ & $\begin{array}{l}\cdots \\
\cdots \\
\cdots \\
\cdots \\
\cdots\end{array}$ & $\begin{array}{c}\text { Per cent. } \\
\cdot 0422 \\
\cdot 0604 \\
\cdot 0575 \\
\cdot 0379 \\
\cdot 0449\end{array}$ & $\begin{array}{l}\text { Indifferent } \\
\text { Fair } \\
\text { Fair } \\
\text { Indifferent } \\
\text { Indifferent }\end{array}$ & $\begin{array}{c}\text { Per cent. } \\
\cdot 0026 \\
\cdot 0030 \\
\cdot 0047 \\
\cdot 0027 \\
\cdot 0026\end{array}$ \\
\hline $\begin{array}{l}20 \\
18 * \\
21 \\
19^{*}\end{array}$ & $\begin{array}{c}\text { Cumnock ... } \\
\text { do } \\
\begin{array}{c}\text { Mungeribar } \\
\text { do } \quad . .\end{array}\end{array}$ & $\begin{array}{l}\cdots \\
\cdots \\
\cdots \\
. .\end{array}$ & $\begin{array}{l}\cdot 0277 \\
.0212 \\
\cdot 0706 \\
.0447\end{array}$ & $\begin{array}{l}\text { Bad } \\
\ldots \ldots \ldots \ldots . . . . \\
\text { Fair } \\
\ldots \ldots \ldots \ldots . . . .\end{array}$ & $\begin{array}{l}\cdot 0025 \\
\ldots \ldots \ldots \ldots \\
\cdot 0124 \\
\cdot 0035\end{array}$ \\
\hline $\begin{array}{l}4 \\
5 * \\
6 \\
7^{*} \\
9 \\
8 * \\
13 \\
12^{*}\end{array}$ & 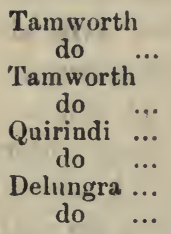 & $\begin{array}{l}\ldots \\
\ldots \\
\ldots \\
\ldots \\
\cdots \\
\cdots \\
\cdots\end{array}$ & $\begin{array}{l}\cdot 1612 \\
\cdot 0902 \\
\cdot 1237 \\
\cdot 0633 \\
\cdot 0656 \\
\cdot 0367 \\
\cdot 0795 \\
\cdot 0362\end{array}$ & $\begin{array}{l}\text { Satisfactory } \\
\text { Sa.......... } \\
\text { Satisfactory } \\
\text { Fair ...... } \\
\text { Fair ....... } \\
\text {............... }\end{array}$ & $\begin{array}{l}\cdot 0106 \\
\ldots \ldots \ldots . . \\
.0029 \\
.0010 \\
\cdot 0148 \\
.0064 \\
.0128 \\
.0088\end{array}$ \\
\hline
\end{tabular}

* Subsoil.

It will be seen that only in some cases were samples of the subsoil submitted, and in view of this in ompleteness, the figures relating to the subsoils may be discarded. 
$\Lambda$ comparison of the $\mathrm{P}_{2} \mathrm{O}_{6}$ content with the known response to the application of superphosphate is shown in the following table:-

TABLE V.-Showing comparison of $\mathrm{P}_{2} \mathrm{O}_{5}$ content with response to application of Superphosphate.

\begin{tabular}{|c|c|c|c|c|c|}
\hline Soil No. & Locality. & & $\begin{array}{c}\text { Result of } \\
\text { Supurphosphate. }\end{array}$ & Total $\mathrm{I}_{2} \mathrm{O}_{5}$ & Araiiable $\mathbf{P}_{2} \mathrm{O}_{5}$, \\
\hline $\begin{array}{r}2 \\
3 \\
10 \\
11 \\
22\end{array}$ & $\begin{array}{ll}\text { Wagga } & \ldots \\
\text { Henty } & \ldots \\
\text { Lockhart } & \ldots \\
\text { Albury } \quad \ldots \\
\text { Narrandera }\end{array}$ & $\begin{array}{l}\cdots \\
\cdots \\
\cdots \\
\cdots \\
\cdots\end{array}$ & $\begin{array}{cc}\text { Responsive } & \ldots \\
\text { do } & \ldots \\
\text { do } & \ldots \\
\text { do } & \ldots \\
\text { do } & \ldots\end{array}$ & $\begin{array}{c}\text { Per cent. } \\
.0422 \\
0604 \\
\cdot(0575 \\
.0379 \\
.0449\end{array}$ & $\begin{array}{c}\text { Per cent. } \\
.0026 \\
.0030 \\
.0047 \\
.0027 \\
.0026\end{array}$ \\
\hline $\begin{array}{l}20 \\
21\end{array}$ & $\begin{array}{l}\text { Cumnock ... } \\
\text { Mungeribar }\end{array}$ & $\begin{array}{l}\ldots \\
\ldots\end{array}$ & $\begin{array}{l}\text { Responsive } \\
\text { Unresponsive }\end{array}$ & $\begin{array}{l}\cdot 0277 \\
\cdot 0706\end{array}$ & $\begin{array}{l}\cdot 0025 \\
\cdot 0124\end{array}$ \\
\hline $\begin{array}{r}4 \\
6 \\
9 \\
13\end{array}$ & $\begin{array}{l}\begin{array}{l}\text { Tamworth } \\
\text { do }\end{array} \\
\text { Quirindi ... } \\
\text { Delungra ... }\end{array}$ & $\begin{array}{l}\cdots \\
\cdots \\
\cdots \\
\cdots\end{array}$ & $\begin{array}{l}\text { Unresponsive } \\
\text { Responsive } \\
\text { Unresponsive } \\
\text { do }\end{array}$ & $\begin{array}{l}\cdot 1642 \\
\cdot 1237 \\
\cdot 0656 \\
\cdot 0795\end{array}$ & $\begin{array}{l}\cdot 0106 \\
\cdot 0029 \\
\cdot 0148 \\
\cdot 0128\end{array}$ \\
\hline
\end{tabular}

Though the number of soils investigated is comparatively small, there is shown a relation between the responsiveness of the soil and the contained amount of $\mathrm{P}_{2} \mathrm{O}_{5}$; that is to say, there is an analytical reason for the variation in the responsireness of the wheat soils to superphosphate.

There is not a constant relation between the amount of total $\mathrm{P}_{2} \mathrm{O}_{5}$ and the amount of available $\mathrm{P}_{2} \mathrm{O}_{5}$ present, and of the two determinations, as a means of determining the responsiveness or otherwise of a soil, that of the available $\mathrm{P}_{2} \mathrm{O}_{5}$ would appear to be of greater value than the detrminntion of the total $\mathrm{P}_{2} \mathrm{O}_{5^{*}}$. There are some striking instances of this in the forcgoing table.

In the ease of the Mungeribar soil in which the total $\mathrm{P}_{2} \mathrm{O}_{5}$ would be considered only "fair," there is a notably high amount of available $\mathrm{P}_{2} \mathrm{O}_{3}$ present, which would indicate that there is not likely to be a response to the application of superphosphate. Similarly in the case of the soils from Quirindi and Delungra.

On the other hand, Soil No. 6 from Tamworth shows a "satisfactory" amount of total $P_{2} \mathrm{O}_{5}$, while the amount of available $\mathrm{P}_{3} \mathrm{O}_{5}$ is very low, and would at once lead to the conclusion that the application of superphosphate would provo beneficial.

Further, althougi $\mathrm{i}_{\mathrm{i}}$ it is scarcely fair to try and arrive at a definite figure from such a small number of soils, there are indications that the amount of available $\mathrm{P}_{2} \mathrm{O}_{5}$ above which the application of superphosphate will not be necessary, is somewhere between $\cdot 0047$ and $\cdot 01$ per cent. Dyer stated that if the amount of available $\mathrm{P}_{2} \mathrm{O}_{5}$ fell below 01 per cent., a phosphatic fertiliser would be beneficial. But it is possible that a lower figure should be 
accepted for New South Wales conditions, and referring solely to the wheat crop. It is of interest to know that the Department of Agriculture in the Transvaal, after numerous analyses of soils of known cropping powers, arrived at the conclusion that if the amount of available $\mathrm{P}_{2} \mathrm{O}_{5}$ fell below .005 per cent., a phosphatic fertiliser was required for the maize crop.

In conclusion, the results obtained from the small number of soils treated are sufficient to indicate that further research along similar lines, but covering a much wider range of soils, is desirable, and likely to lead to results of value.

My grateful thanks are due and hereby tendered to Professor Watt and Mr. G. Wright, Lecturer in Agricultural Chemistry, for the constant help and advice given while carrying out the work. 




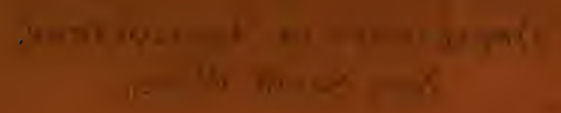

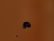
2nitsllud sonsibe

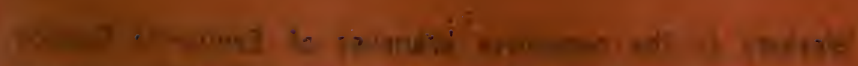

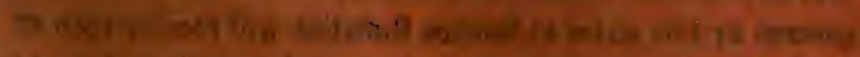

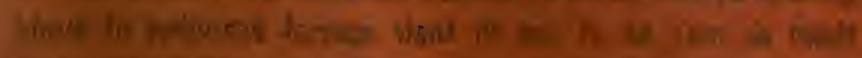

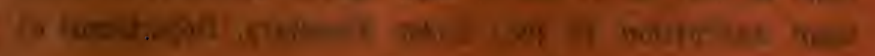

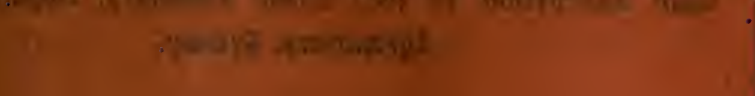

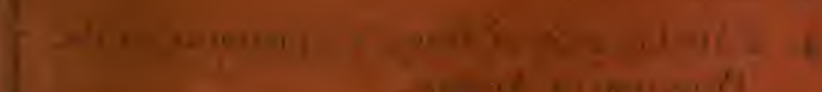

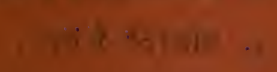

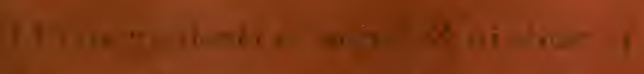

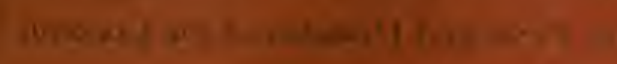

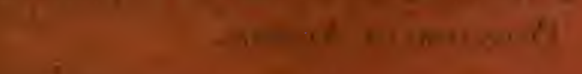

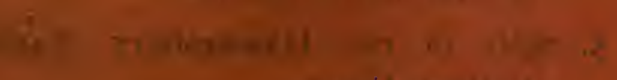

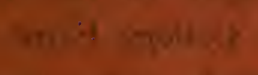

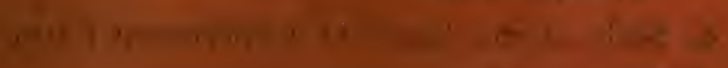

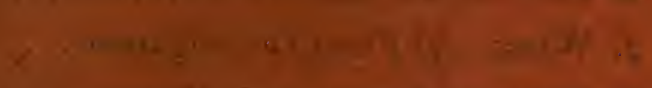

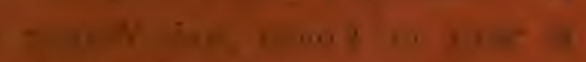

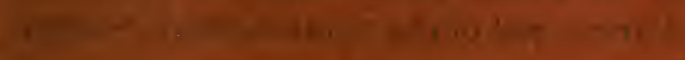

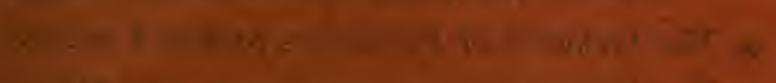

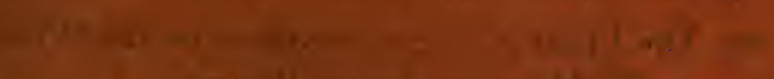

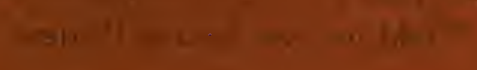


Department of Agriculture, New South Wales.

\section{Science Bulletins.}

Workers in the respective branches of Economic Science covered by this series of Science Bulletins will receive st:ch of them as may be of use in their special branches of study upon application to the Under Secretary, Department of Agriculture, Sydney.

1. Soils in Relation to Geology and Climate.

2. Pests and Diseases of the Coconut Palm.

3. March Flies.

4. A Modification of Marsh's Apparatus for the Detection of Arsenic.

5. Soils of the Hawkesbury Agricultural College Farm.

6. Soils of the Bathurst Experiment Farın.

7. Wheut and Flour Investigations.

8. Soils of Cowra and Wagga Experiment Farms, and of the South-western Slopes.

9. The Relation of Fertilisers to Soil Fertility.

10. The Effect of Superphosphate on the IVheat Yield in New South Wales. 





\section{DAY USE}

RETURN TO

AGRICULTURE LIBRARY

40 Glannini Hall - Tol. No. 642-448

This publication is due on the LAST DATE and HOUR stamped below.

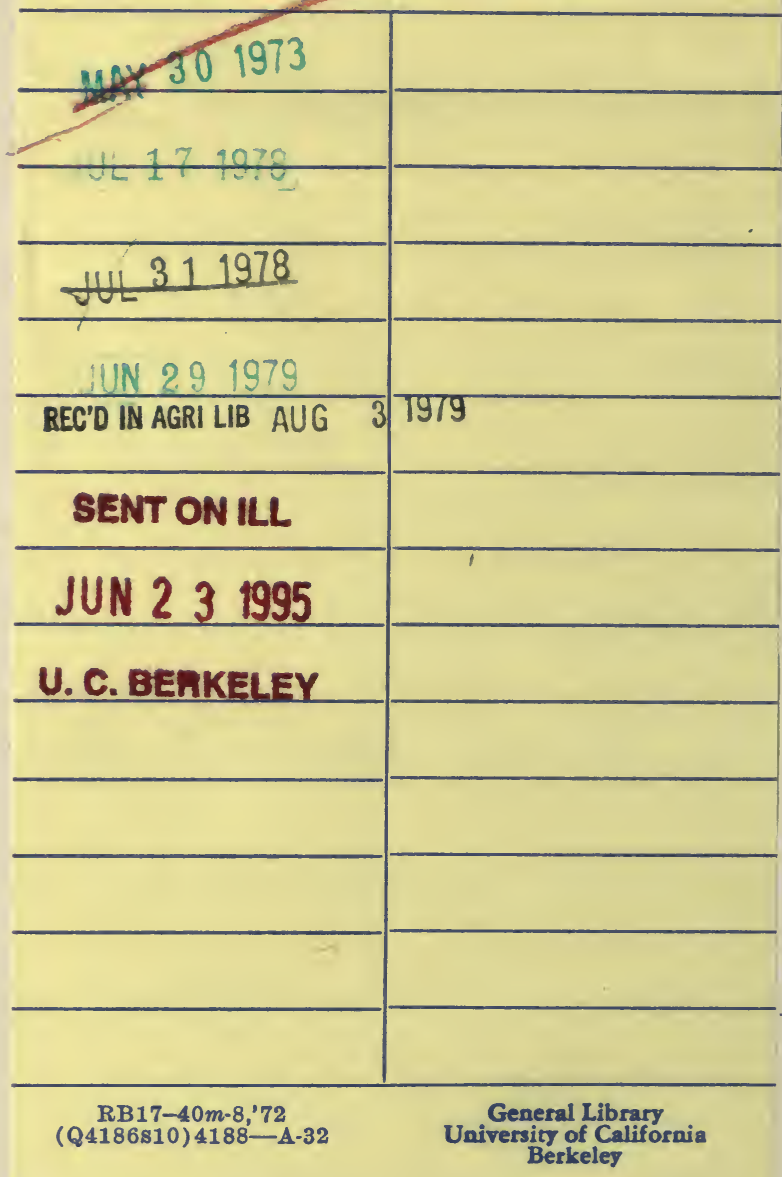




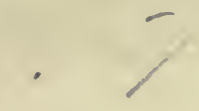

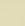

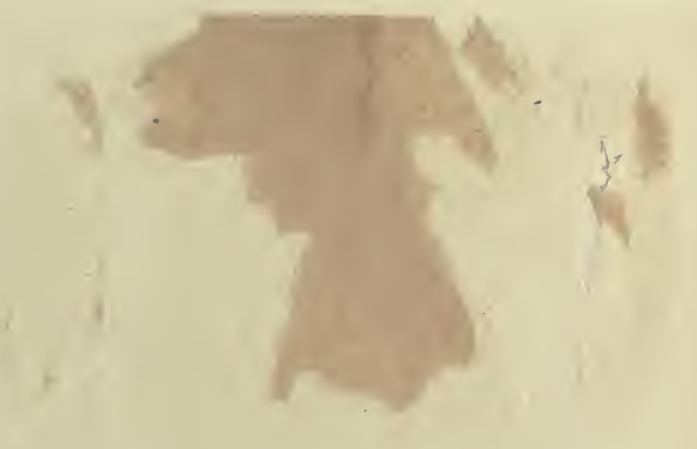

$\because !$

$\because 4$
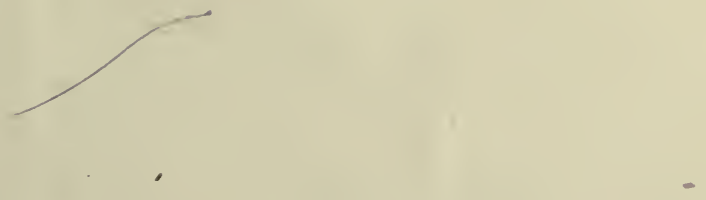
